\title{
Neuraminidase-deficient Sendai virus HN mutants provide protection from homologous superinfection
}

\author{
Christine A. Baumann · Wolfgang J. Neubert
}

Received: 14 July 2009/ Accepted: 6 November 2009/Published online: 19 December 2009

(C) The Author(s) 2009. This article is published with open access at Springerlink.com

\begin{abstract}
Binding of hemagglutinin-neuraminidase proteins (HN) to sialylated receptors initiates the infection process of several paramyxoviruses, whereas later in the viral life cycle, the neuramindase (NA) activity of newly synthesized HN destroys all receptors. Prior to NA action, expressed HN has to bind the receptor. To evaluate this $\mathrm{HN}-$ receptor complex with respect to receptor inactivation, three temperature-sensitive Sendai virus HN mutants carrying amino acid exchanges at positions 262, 264 and/or 461 were created that uncoupled NA activity from receptor binding at $39^{\circ} \mathrm{C}$. Interestingly, at elevated temperature, when there is no detectable neuramindase activity, all infected cells are protected against homologous superinfection. Mutated HN protein on the cell surface is mainly bound to sialylated cell-surface components but can be released by treatment with NA. Thus, continuous binding to $\mathrm{HN}$ already inactivates the receptors quantitatively. Furthermore, mutant $\mathrm{HN}$ bound to receptors is prevented from being incorporated into virus particles in the absence of NA. It is shown here for the first time that during paramyxoviral infection, quantitative receptor inactivation already occurs due to binding of receptors to expressed $\mathrm{HN}$ protein without involvement of NA and is independent of NA activity of viral progeny. NA subsequently functions in the release of HN from the complex, coupled with desialysation of receptors. These findings could have implications for further antiviral drug development.
\end{abstract}

C. A. Baumann · W. J. Neubert $(\bowtie)$

Department of Molecular Virology,

Max Planck Institute of Biochemistry,

Am Klopferspitz 18, 82152 Martinsried, Germany

e-mail: neubert@biochem.mpg.de

\section{Introduction}

Hemagglutinin-neuraminidase glycoproteins $(\mathrm{HN})$ in the envelope of several paramyxoviruses initiate the infection process by binding to cellular receptors. Later in the viral life cycle, $\mathrm{HN}$ expressed on the cell surface is thought to cause destruction of the receptor, thereby preventing re-infection by viral progeny and also homologous superinfection [22]. Both $\mathrm{HN}$ functions are based on its affinity for sialylated receptors [6, 42]. Diverse sialic-acid-containing cell-surface components have been characterized [9, 19, 37], and structural studies on HN from NDV, hPIV3 and SV5 suggest that one structurally flexible sialic-acid-recognition site of $\mathrm{HN}$ switches between a binding and a catalytic function $[4,16$, 43]. This concept of a bifunctional HN site is further supported by work showing that both functions could be simultaneously reduced or even abolished through the binding of monoclonal antibodies or neuraminidase (NA) inhibitors [12, 28, 41]. Using hemadsorption assays, it has been shown that mutated HN, generated in transduced cells, shows both reduced NA and reduced receptor-binding activity [3, 13]. Hence, it seems that $\mathrm{HN}$ mutations induce a defect in both functions simultaneously and that generation of an $\mathrm{HN}$ protein that possess functional receptor-binding activity but lacks NA activity should not be possible.

Until now, a possible participation of the receptorbinding function in the process of receptor destruction could not be examined using live virus. In earlier studies on cell lines persistently infected with Sendai virus $(\mathrm{SeV})$ $[14,40]$, we demonstrated protection against homologous superinfection, although hemadsorption specific for $\mathrm{HN}$ on the cell surface was reduced by 50\% [25]. In parallel, a strong decrease in NA activity was detectable through the inability to release hemagglutinated erythrocytes at $37^{\circ} \mathrm{C}$ from virus-erythrocyte complexes. Based on these 
findings, we hypothesized that viruses from persistent infections could contain an $\mathrm{HN}$ with uncoupled receptorbinding and receptor-destroying functions: $\mathrm{HN}$ bound to receptors would not be released for binding another substrate as long as NA is not active and-as a consequenceincorporation of $\mathrm{HN}$ into viral progeny could be hindered. If the same mechanism would also apply to wild-type (wt) infections, such findings could be relevant for further development of antiviral drugs, which are currently mainly focused on neuraminidase inhibition. However, in wildtype infections, both processes occur very quickly due to the high efficiency of NA and therefore could not be investigated separately so far.

We decided to test our hypothesis under natural conditions by infecting cells with $\mathrm{SeV}$ mutants carrying selected mutations in the HN gene suspected to be responsible for NA deficiencies. A 30\% reduced NA activity was reported for SeV Enders strain mutant ts 271, which has amino acid exchanges at positions 262, 264 and $461[29,30]$ compared to Enders wt, but this mutant is no longer available. Compared to Sendai strain Fushimi HN, the Enders HN shows a reduction in NA activity of $35 \%[8,39]$ due to the aa exchange $\mathrm{E} 461 \mathrm{~K}$; therefore, we decided to create mutants based on the Fushimi backbone.

The HN mutants examined in the present work possess the amino acid exchanges A262T+G264R+E461K, $\mathrm{A} 262 \mathrm{~T}+\mathrm{E} 461 \mathrm{~K}$ or $\mathrm{A} 262 \mathrm{~T}+\mathrm{G} 264 \mathrm{R}$. Exchanges at positions 262 and 264 are equivalent to those of mutant ts 271 , and an exchange at position 461 corresponding to that in the Enders strain should further decrease NA activity. To demonstrate NA-independent receptor inactivation by these mutants specifically, homologous superinfection assays with a Sendai challenge virus carrying an eGFP reporter gene were employed as a very sensitive approach.

The three $\mathrm{SeV} \mathrm{HN}$ mutants presented here showed a temperature-dependent decrease in NA activity to undetectable levels when the proteins were expressed at elevated temperature. Binding of mutated $\mathrm{HN}$ to sialylated receptors of infected cells already prevented homologous superinfection, independent of NA activity.

\section{Materials and methods}

Cells and virus infection

LLC-MK $\mathrm{MK}_{2}$ cells (Rhesus monkey kidney, ATCC no. CCL 7.1) were purchased from Flow Laboratories and were maintained in Dulbecco's modified Eagle's medium (DMEM) supplemented with $10 \%$ fetal calf serum (FCS).

Cell monolayers were consistently infected with Sendai virus at an m.o.i. of $\geq 4$ to achieve HN synthesis in $\geq 98 \%$ of the cells. Virus adsorption was generally performed at $33^{\circ} \mathrm{C}$ for $1 \mathrm{~h}$, after which cells were incubated in serumfree DMEM $\left(\mathrm{DMEM}^{-}\right)$at the indicated temperatures.

\section{Virus stock and FLAT assay}

Virus stocks were prepared by infecting cell monolayers for $46 \mathrm{~h}$ at $33^{\circ} \mathrm{C}$. Virus particles were activated by cleavage of the $F_{0}$ protein into $F_{1}$ and $F_{2}$ by treatment with acetylated trypsin $(4 \mu \mathrm{g} / \mathrm{ml}$ final concentration) for $1 \mathrm{~h}$. Virus stocks were stored in the vapor phase of liquid $\mathrm{N}_{2}$.

Virus titers were determined by the fluorescence-linked antibody titer (FLAT) assay. Cell monolayers $\left(2 \times 10^{5}\right.$ cells) in 24-well plates were infected with ten-fold serially diluted virus suspensions and incubated at $33^{\circ} \mathrm{C}$. Two days later, the cells were fixed with methanol. Intracellular viral proteins were detected with monospecific anti- $\mathrm{N}$ antibodies generated in our laboratory, followed by incubation with anti-rabbit antibodies labeled with Alexa Fluor 568 fluorescence dye (Molecular Probes). Fluorescent positive cells were counted.

\section{Generation of recombinant Sendai virus ( $\mathrm{rSeV}$ ) HN mutants and $\mathrm{rSeV}$ P-EGFP}

The construction of the complete cDNA of SeV (Fushimi strain) has been described previously [17, 18]. Mutations in the $\mathrm{SeV}$ genome at positions 7,476, 7,482 and 8,073 were generated by using synthetic oligonucleotide primers, the ExSite PCR-based mutagenesis kit (Stratagene, La Jolla), the fusion PCR technique and standard cloning techniques [11]. The presence of the desired mutations in the three different $\mathrm{HN}$ mutants was confirmed by nucleotide sequencing. Details of the stepwise generation of the mutated genomic cDNA can be obtained from the authors on request.

Generation of rSeV P-eGFP, which has the enhanced green fluorescent protein (eGFP) gene inserted after the $\mathrm{P}$ gene, has been described previously [2]. Rescue of the recombinant $\mathrm{SeV} \mathrm{HN}$ mutants was performed with MVA-T7 vaccinia virus as described previously $[18,33,36]$.

Generation of recombinant measles virus P-DsRed

The construction and generation of the recombinant measles virus P-DsRed (Schwarz strain, Mérieux ${ }^{\mathrm{TM}}$ ) with a Discosoma red (DsRed) gene inserted after the $\mathrm{P}$ gene was performed essentially as described previously [21].

Western blot analysis of cellular and viral proteins

Cell infection was performed in T75 Roux bottles $\left(6 \times 10^{6}\right.$ cells) as described above. After incubation for $47 \mathrm{~h}$, the culture medium was collected for virus purification. 
Supernatants of infected cells were clarified from cell debris by centrifugation at $700 \mathrm{~g}$, and virus particles were pelleted at 30,000 rpm. $(154,000 \mathrm{~g})$. The virus pellet was solubilized in RIPA buffer, and the protein concentration was determined. Infected cell monolayers were washed and collected in DMEM ${ }^{-}$. The cells were lysed in RIPA buffer [32], and DNA was disrupted by sonification (LKB Instruments). The protein concentration of each sample was determined by the Lowry technique [26].

Cellular and viral proteins were analyzed by western blot after separation on a $10 \%$ sodium dodecyl sulfate polyacrylamide gel. The proteins were transferred to an Immobilon-PVDF membrane (Millipore) by electroblotting in Tris-glycine buffer (20 mM Tris-HCl, pH 8.8, $150 \mathrm{mM}$ glycine) at $400 \mathrm{~mA}$ for $6.5 \mathrm{~h}$. The membranes were blocked with Roti-Block (Carl Roth $\mathrm{GmbH}$ ), a polymerbased blocking reagent, and then incubated for $1 \mathrm{~h}$ in $\mathrm{HN}$ or N-protein-specific antibodies, which were generated in our laboratory. The blot was rinsed with TBST $(10 \mathrm{mM}$ Tris-HCl, $\mathrm{pH} 8.8,150 \mathrm{mM} \mathrm{NaCl}, 0.05 \%$ Tween 20 ) and incubated with peroxidase-conjugated anti-mouse or antirabbit antibody (Dako) diluted in TBST. ECL western blotting reagents (Amersham Biosciences) were used for chemiluminescence detection.

\section{Cell-surface immunofluorescence}

Cells grown on glass slides were infected for $24 \mathrm{~h}$ at 33 or $39^{\circ} \mathrm{C}$. The cells were incubated with anti-HN monoclonal antibody S2, courteously provided by Portner et al. [31]. It was added to the living cells for $1 \mathrm{~h}$ at room temperature. After washing the cell monolayers, the cells were fixed for 10 min with $100 \%$ methanol. HN protein-antibody complexes were made visible by incubation in anti-mouse Alexa Fluor 568-conjugated antibody (Molecular Probes) for $1 \mathrm{~h}$. Cells were photographed at $200 \times$ magnification.

Erythrocyte binding assay and treatment of infected cells with Vibrio cholerae neuraminidase (V.C. NA)

Erythrocytes of type $\mathrm{O}$ were freshly obtained from human blood. Cells were seeded in 24-well plates with $1.6 \times 10^{5}$ cells/well and incubated for 1 day at $37^{\circ} \mathrm{C}$. Subsequently, the cell monolayers were infected for $24 \mathrm{~h}$ as described above. Hemadsorption activity (HAd) was determined using a $0.5 \%$ erythrocyte suspension in serum-free medium. After washing the cells, erythrocytes were added in $\mathrm{DMEM}^{-}$for $1 \mathrm{~h}$ at $4^{\circ} \mathrm{C}$. Unbound erythrocytes were removed by washing, and the percentage of hemadsorption-positive cells was determined. Alternatively, the hemoglobin content of bound erythrocytes was determined: Erythrocytes were eluted by treatment for $2 \mathrm{~h}$ at $37^{\circ} \mathrm{C}$ with $1 \mathrm{mU}$ of V.C. NA (Sigma), pelleted and lysed in $50 \mathrm{mM}$
$\mathrm{NH}_{4} \mathrm{Cl}$. The lysate was clarified by centrifugation, and the absorbance of the hemoglobin was measured at $450 \mathrm{~nm}$ using a microtiter plate reader (Dynatech MR7000).

V.C. NA treatment was performed $23 \mathrm{~h}$ after cell infection at the temperature used for production of $\mathrm{HN}$ proteins. The monolayer was washed with $\mathrm{DMEM}^{-}$, and $10 \mathrm{mU}$ of V.C. NA was added in $250 \mu \mathrm{LMEM}^{-}$for $1 \mathrm{~h}$. HAd activity was determined after removing the enzyme.

Detection of neuraminidase activity by substrate cleavage

Assays were performed in T12.5 Roux bottles $\left(1 \times 10^{6}\right.$ cells). Monolayers were infected as described above. Cells were washed and subsequently incubated in $0.4 \mathrm{ml}$ colorless Medium 199 (Gibco-Invitrogen) without FCS. NAe substrate X-Neu5Ac (5-bromo-4-chloro-3-indolyl $\alpha$-D- $N$ acetylneuraminic acid, $0.2 \mu \mathrm{mol}$ ) (Sigma) [7] was added for $1 \mathrm{~h}$ at the indicated infection temperatures. Afterward, the supernatant was centrifuged through an Ultrafree-MC centrifugal filter unit (Millipore) for $2 \mathrm{~min}$ at $8,000 \mathrm{~g}$ (Beckman centrifuge), and the flow-through was transferred to a polystyrol cuvette. NA activity converted $\mathrm{X}$-Neu5Ac to the blue pigment 5,5'-dibromo-4,4'-dichloro indigo, which was quantified $24 \mathrm{~h}$ later at $660 \mathrm{~nm}$ in a spectrophotometer (Beckman).

\section{Superinfection assays}

Assays were performed in T25 Roux bottles $\left(2 \times 10^{6}\right.$ cells). Primary infection was carried out as described above. The infected cells were washed $24 \mathrm{~h}$ later with $\mathrm{DMEM}^{-}$. Homologous superinfection was initiated by adding rSeV P-eGFP [2] at an m.o.i. of $\geq 4$. Measles virus P-DsRed at an m.o.i. of $\geq 2$ was used for heterologous superinfection. The challenge virus was allowed to adsorb for $1 \mathrm{~h}$ at the temperatures used for primary infection. Cells were inspected for eGFP or DsRed after 2 and 3 days, respectively.

\section{Results}

Production of $\mathrm{SeV} \mathrm{HN}$ mutants and characterization of the expressed HN proteins

HN mutants HN-262+264+461 (A262T+G264R+E461K), $\mathrm{HN}-262+461(\mathrm{~A} 262 \mathrm{~T}+\mathrm{E} 461 \mathrm{~K})$ and $\mathrm{HN}-262+264(\mathrm{~A} 262 \mathrm{~T}+$ G264R), based on wild-type (wt) SeV Fushimi strain, were generated using our well-established virus rescue system [18]. Efficient amplification of stock viruses at $33^{\circ} \mathrm{C}$ already confirmed the functional receptor binding of the mutants. Mutant virus titers of about $10^{8}$ infectious particles $/ \mathrm{ml}$ 
(HN 262+264+461 $3.3 \times 10^{8} / \mathrm{ml}$, HN $262+4612.1 \times$ $10^{8} / \mathrm{ml}$, HN $262+2642.9 \times 10^{8} / \mathrm{ml}$ ) were comparable to those of wt virus $\left(5.1 \times 10^{8} / \mathrm{ml}\right)$, as determined by FLAT assay. This method was used for quantifying infectious $\mathrm{HN}$ mutants with presumably reduced efficiency for plaque formation or binding of erythrocytes. Western blot analysis of viral HN showed distinct signals without significant differences in quantity and quality between mutated and wildtype proteins (Fig. 1a).

In the next step, the stable and efficient expression of mutant $\mathrm{HN}$ proteins in infected cells at 33 and $39^{\circ} \mathrm{C}$ was analyzed. Infections were generally performed using an m.o.i. of $\geq 4$, virus particles were adsorbed at $33^{\circ} \mathrm{C}$, and cells were incubated at 33 or $39^{\circ} \mathrm{C}$. HN in cell extracts prepared $46 \mathrm{~h}$ later were analyzed by immunoblot detection. Using a small amount of cell extract $(5 \mu \mathrm{g})$ resulted in clear HN signals with all three mutants at both temperatures without detection of degradation products (Fig. 1a). In contrast to our efficient $\mathrm{HN}$ synthesis, in transduced cells, in which the $\mathrm{HN}$ expression was restricted, either due to a small number of transfected cells and/or a generally low level of expression, $250 \mu \mathrm{g}$ of cell extract or immunoprecipitation of radioactively labeled proteins was required for detection $[10,13]$. Next, mutant $\mathrm{HN}$ expressed on the cell surface was detected in situ by cell-surface immunofluorescence. Incubation with the primary antibody was carried out before cell fixation. In this way, the undesired permeabilization of cell membranes, which could lead to binding of intracellular $\mathrm{HN}$ protein to the antibody, was definitely prevented [5]. Transport to the cell surface was independent of incubation temperature, since mutated $\mathrm{HN}$ were clearly detectable at 33 and $39^{\circ} \mathrm{C}$ (Fig. 1c). HN signals on the cell surface were more regularly distributed compared to the signals of cytoplasmic proteins. Unimpaired expression of mutant $\mathrm{HN}$ and transport to the cell surface were important prerequisites for investigating $\mathrm{HN}-$ receptor complexes.

Finally, the neuraminidase (NA) activity of mutant HN suspected to be decreased at elevated temperature was measured at 33 and $39^{\circ}$. In comparison to wt infected cells, mutant cells infected at $33^{\circ} \mathrm{C}$ revealed significantly reduced but clearly detectable neuraminidase. At $39^{\circ} \mathrm{C}$, activity was undetectable (Fig. 1b). In this assay, even low levels of sialidase activity should be detectable due to repeated

a

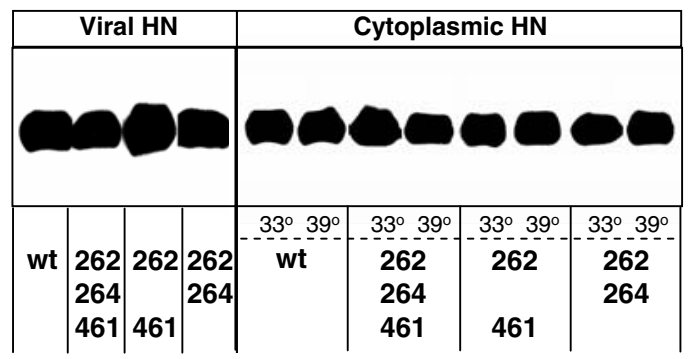
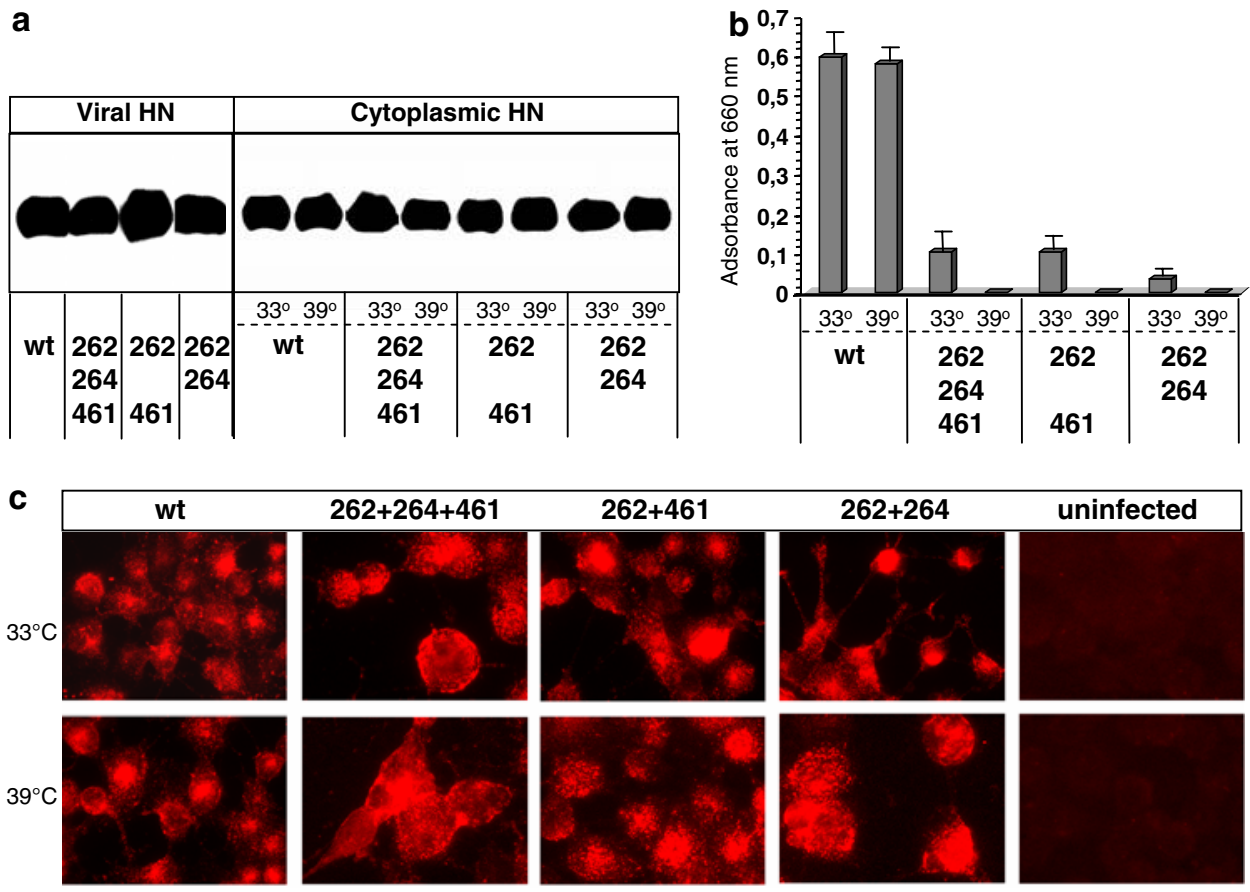

uninfected

Fig. 1 Characterization of mutant HN proteins. LLC-MK 2 cells were infected with wt $\mathrm{SeV}$ or $\mathrm{HN}$ mutants at an m.o.i. of $\geq 4$. a For detection of $\mathrm{HN}$ protein in virus particles, cells were cultured at $33^{\circ} \mathrm{C}$ for $47 \mathrm{~h}$. Virus particles were concentrated by ultracentrifugation of cell supernatants. Virus pellets were solubilized in RIPA buffer, and the protein concentration was determined. Virus proteins $(1 \mu \mathrm{g}$ per lane) were separated by SDS-PAGE. Immunodetection was performed with an $\mathrm{HN}$-specific (VII3c-4F) monoclonal antibody. For detection of cytoplasmically expressed viral proteins, cells were cultured at 33 or $39^{\circ} \mathrm{C}$ for $46 \mathrm{~h}$. Cell extracts were prepared, and proteins $(5 \mu \mathrm{g}$ per lane) were separated by SDS-PAGE. Immunodetection was performed with an $\mathrm{HN}$-specific (VII3c-4F) monoclonal antibody. b Neuraminidase assays were carried out $24 \mathrm{~h}$ after infection with X-Neu5Ac as substrate [7]. c For detection of mutant $\mathrm{HN}$ on the cell surface by immunofluorescence, binding of anti-HN S2 antibodies [30] was performed $24 \mathrm{~h}$ after infection, followed by fixation with methanol. Anti-mouse Alexa Fluor 568-conjugated antibody was used as a secondary antibody 
binding and cleavage of the synthetic substrate. However, when the substrate incubation time was extended to $4.75 \mathrm{~h}$, we again failed to detect any enzymatic activity (data not shown). In summary, cytoplasmic mutant HN synthesis and its transport to the cell surface are not impaired and NA activity is undetectable at $39^{\circ} \mathrm{C}$, as proposed. Therefore, these virus mutants should be useful tools for investigating possible influences of $\mathrm{HN}-$ receptor complexes on receptor inactivation.

Homologous superinfection by challenge virus carrying a reporter gene

Superinfection assays should be employed for very sensitive detection of functional receptors on the cell surface. Homologous superinfection can be detected easily by using recombinant $\mathrm{SeV}$ P-eGFP as challenge virus, which contains the gene for the enhanced green fluorescent protein (eGFP) [2]. To optimize this system, LLC-MK 2 cells infected with wt $\mathrm{SeV}$ were analyzed for protection against superinfection 5 and $24 \mathrm{~h}$ p.i. to mimic the unprotected and the protected state, respectively. We assumed that progression to the protected state depends on the synthesis of increasing amounts of $\mathrm{HN}$ during the course of infection. As shown in Fig. 2a, distinct eGFP signals indicated homologous superinfection of cells infected with wt $\mathrm{SeV}$ for $5 \mathrm{~h}$ and with challenge virus for 2 days. Due to the mixed infection with SeV P-eGFP and wt SeV, eGFP signals were less intense than in cells infected only with SeV P-eGFP (Fig. 3a, SeV-eGFP infection). However, when the challenge was performed $24 \mathrm{~h}$ after primary infection, homologous superinfection was no longer detected (Fig. 2b). As a control, primary infection by $\mathrm{SeV}$ wt was detectable in all cells by FLAT assay (Fig. 2c). The newly developed method of homologous superinfection by challenge virus carrying a reporter gene confirmed that $\mathrm{SeV}$ wt infection enables cells to build up quantitative protection against further homologous virus infections within $24 \mathrm{~h}$. Moreover, this technique proved to be a sensitive system for in situ detection of non-inactivated $\mathrm{SeV}$ receptors on the surface of individual cells.
HN $262+264+461$ and HN $262+461$ protein expression induces protection against homologous superinfection

Homologous superinfection assays were employed to test infected but NA-negative cells for presentation and accessibility of functional $\mathrm{SeV}$ receptors on the cell surface. LLC-MK $\mathrm{MK}_{2}$ cells were infected with $\mathrm{HN}$ mutants. After $24 \mathrm{~h}$, one set of infected cultures was subjected to hemadsorption tests, the other treated with challenge virus. After incubation with challenge virus for $47 \mathrm{~h}$, there was a lack of eGFP signal, indicating that the cells infected with HN $262+264+461$ and HN $262+461$ had been able to develop complete protection against homologous superinfection (Fig. 3a). Interestingly, resistance to $\mathrm{SeV}$ superinfection could be also demonstrated in cells lacking HAd activity. The rare detection of single cells with very intense fluorescence signals (Fig. 3a, 262 $+264+461,33^{\circ} \mathrm{C}$ ) was attributed to cells that remained uninfected by mutant viruses. These strong eGFP-specific signals are comparable to those in cells infected with $\mathrm{SeV}$ P-eGFP alone (Fig. 3a, SeV-eGFP infection).

In contrast, only partial protection against superinfection was achieved in cells infected with mutant HN $262+264$ (Fig. 3a). Homologous superinfection was identified in only a few cells at $33^{\circ} \mathrm{C}$ but by most of the cells at $39^{\circ} \mathrm{C}$ : HN 262+264 was not able to induce a complete and temperature-independent inactivation of receptors. Superinfection was also detectable at an increased m.o.i. of up to 75 as well as after prolonged infection times of up to $48 \mathrm{~h}$ before challenge (data not shown). Quantitative protection against homologous superinfection was finally reached when cells infected at $39^{\circ} \mathrm{C}$ with mutant $\mathrm{HN} 262+264$ were subsequently treated with V.C. NA (Fig. 3a, $262+264+\mathrm{NA})$. Therefore, superinfection at $39^{\circ} \mathrm{C}$ can be interpreted as a temperature-sensitive effect on $\mathrm{HN}$ $262+264$ binding activity.

To exclude any non-specific effects on $\mathrm{HN}$-receptor inactivation due to infection with mutants $\mathrm{HN}$ $262+264+461$ and HN 262+461, heterologous superinfection assays with recombinant measles virus containing
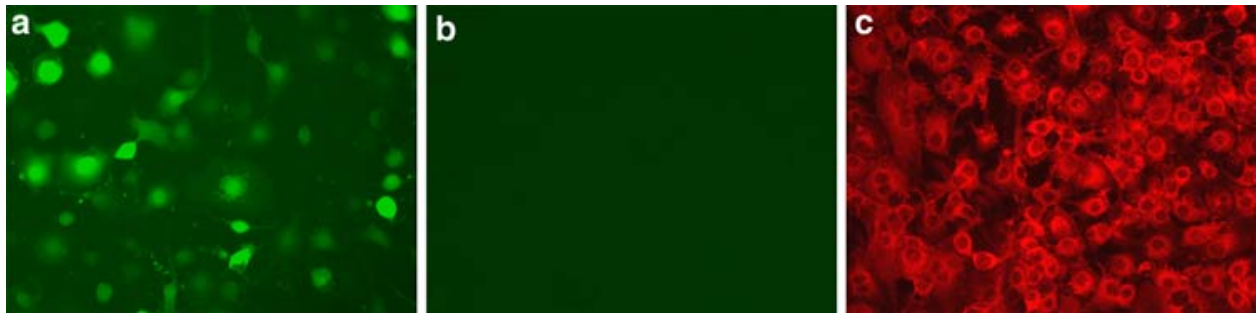

Fig. 2 Optimization of superinfection with homologous SeV. Cells were infected with wt $\mathrm{SeV}$ at $33^{\circ} \mathrm{C}$ (m.o.i. > 4) and challenged after $5 \mathrm{~h}$ a or $24 \mathrm{~h}$ b with SeV P-eGFP (m.o.i. $>4$ ), and eGFP-specific fluorescence was detected after $48 \mathrm{~h}$. c Cells infected with wt $\mathrm{SeV}$ at $33^{\circ} \mathrm{C}$ (m.o.i. > 4) were tested for infection by the FLAT method 

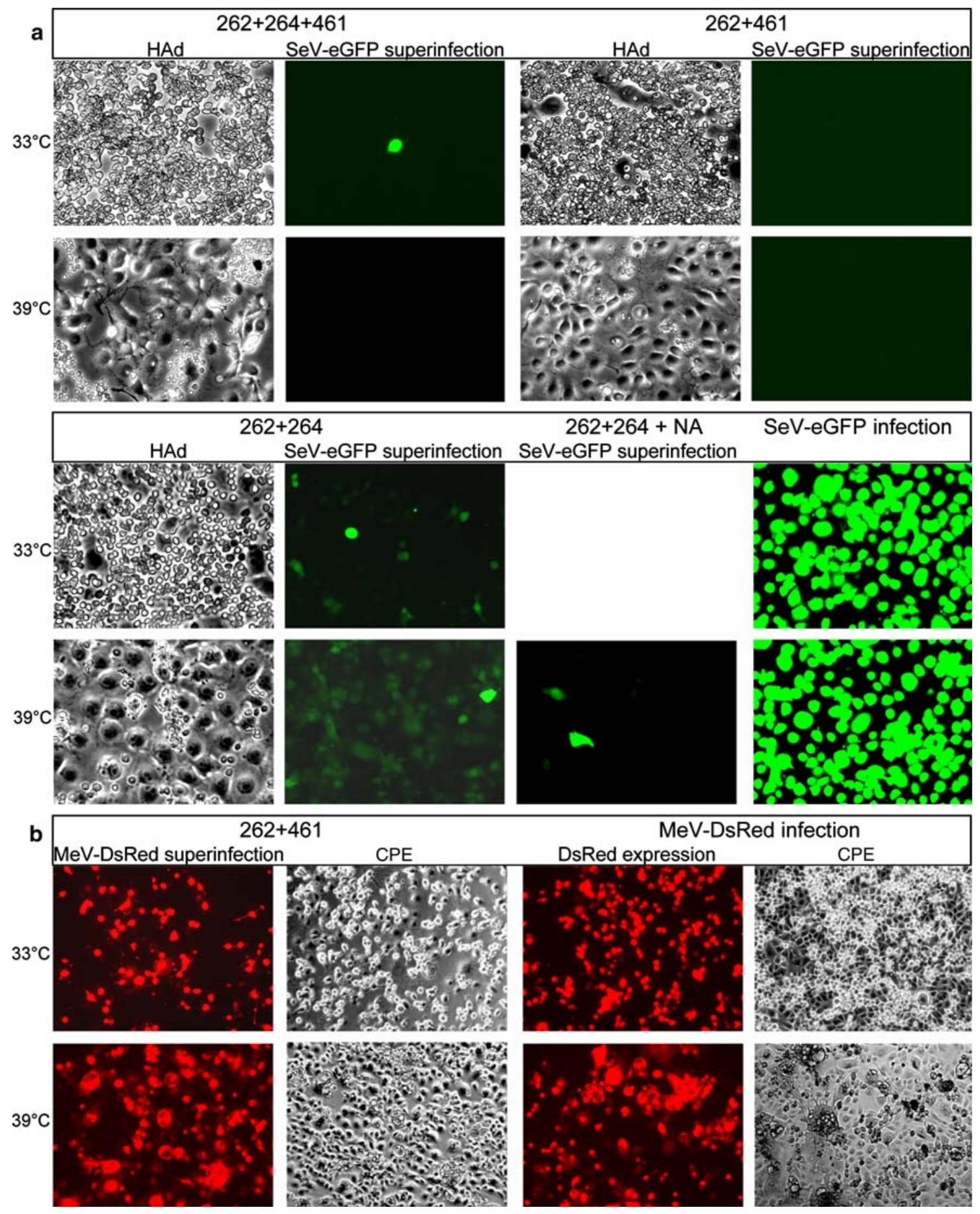

Fig. 3 Protection of SeV HN-mutant-infected cells against superinfection. a LLC-MK 2 cells were infected with one of the three HN mutants (m.o.i. $\geq 6$ ) and subjected to a hemadsorption test $24 \mathrm{~h}$ p.i. (HAd). Parallel cultures were challenged 24 h p.i. with SeV P-eGFP (m.o.i. $\geq 4$ ) and examined for eGFP fluorescence $47 \mathrm{~h}$ after challenge (SeV-eGFP superinfection). HN $262+264$-infected cells $\left(39^{\circ} \mathrm{C}\right)$ were treated additionally for $30 \mathrm{~min}$ with $\mathrm{NA}$ prior to challenge

the DsRed reporter gene (P-DsRed) were also performed. As shown with HN 262+461 infected cells, measles challenge virus infection and replication were not impeded (Fig. 3b).
$(262+264+\mathrm{NA}) ;$ LLC-MK $_{2}$ cells infected only with SeV P-eGFP (SeV-eGFP infection); b LLC-MK 2 cells were infected with mutant $262+461$ and challenged $24 \mathrm{~h}$ later with MeV P-DsRed (m.o.i. $\geq 2$ ) Ds-Red fluorescence was determined $70 \mathrm{~h}$ after challenge (MeVDsRed superinfection). Distinct cytopathic effect (CPE) of cells by heterologous superinfection is shown. Cells were infected with $\mathrm{MeV}$ P-DsRed only (MeV-DsRed infection)

Taken together, infection with NA-deficient mutants protects cells against homologous superinfection. Thus, earlier findings obtained with persistently infected cells [25] could 
Fig. 4 Characterization of receptor binding to mutant $\mathrm{HN}$. a Cells infected with $\mathrm{HN}$ $262+264+461$, HN 262+461 or HN $262+264$ and incubated at $39^{\circ} \mathrm{C}$ for $24 \mathrm{~h}$ were treated with V.C. NA or not treated and tested for erythrocyte binding at $4^{\circ} \mathrm{C}$ (HAd). b, c Cells infected with wt $\mathrm{SeV}$ or $\mathrm{HN}$ mutants at an m.o.i. of $\leq 40$, leading to $100 \%$ HAd activity at $33^{\circ} \mathrm{C}$.

b After incubation for $24 \mathrm{~h}$ at 33 and $39^{\circ} \mathrm{C}$, a $0.5 \%$ suspension of human erythrocytes was added for $1 \mathrm{~h}$ at $4^{\circ} \mathrm{C}$. Unbound erythrocytes were removed, and the percentage of cells covered with erythrocytes was determined. c Infected cells were treated prior to the HAd test with $10 \mathrm{mU}$ V.C. NA for $1 \mathrm{~h}$, and HAd activity was determined after removing the enzyme by extensive cell washing
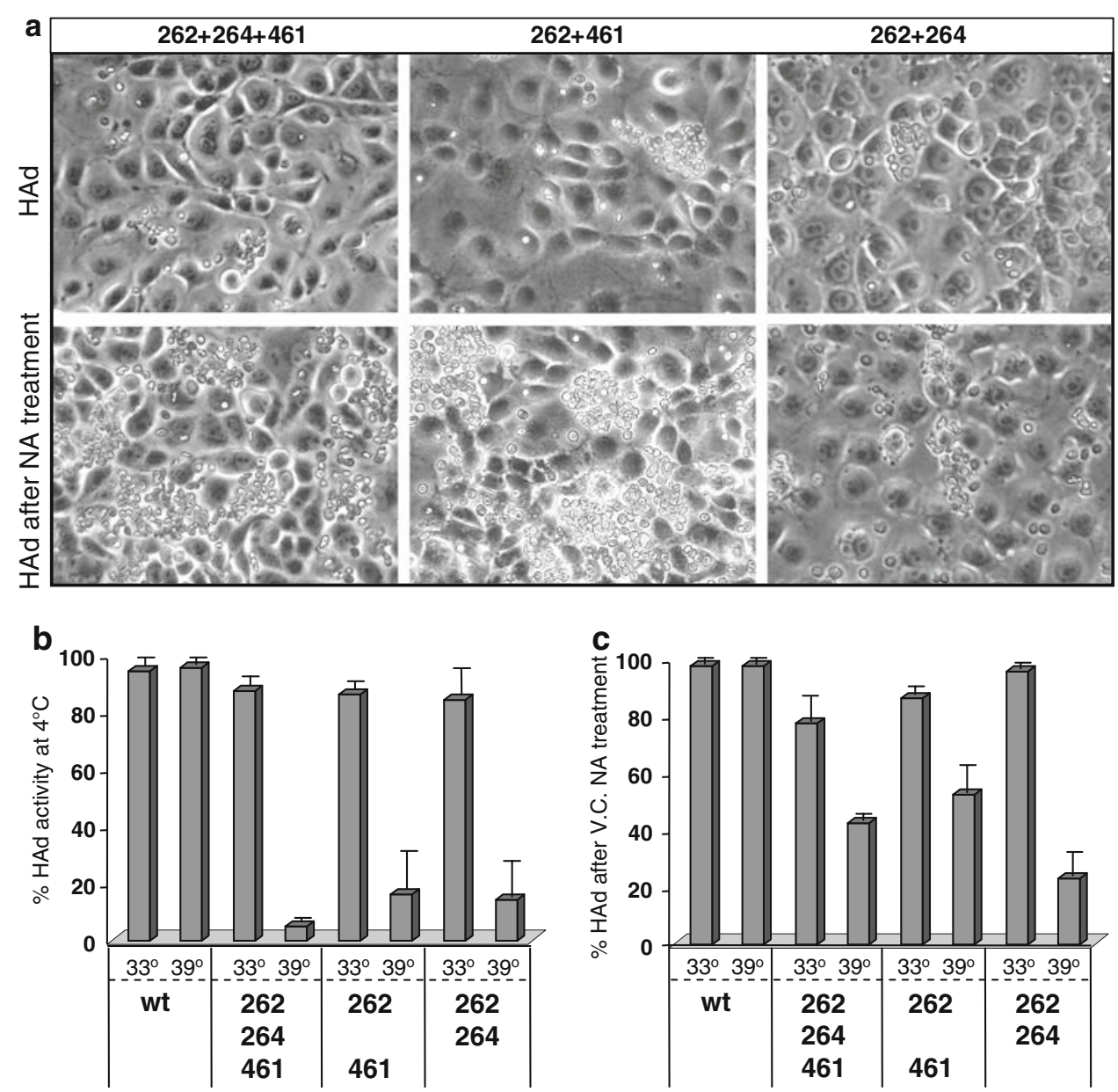

be reproduced by using recombinant virus carrying only two or three defined mutations within the HN gene.

$\mathrm{HN}-$ receptor complexes on the surface of mutant infected cells

Another finding from earlier experimentation with persistently infected cells was a significantly reduced hemadsorption (HAd) activity at elevated temperature. Theoretically, mutated HN protein whose receptor-binding site is occupied by sialic acid should not be able to bind additional ligands. Therefore, mutated $\mathrm{HN}$ on the cell surface were tested for HAd activity. When infected with wt virus, all cells were capable of binding erythrocytes at both temperatures, 33 and $39^{\circ} \mathrm{C}$ (Fig. 4 b). A comparable situation was found when cells were infected with $\mathrm{HN}$ mutants at $33^{\circ} \mathrm{C}$, showing $\leq 85 \%$ HAd activity (Figs. 3a, $4 \mathrm{~b})$. However, when infection with the mutants was carried out at $39^{\circ} \mathrm{C}$, the HAd activity decreased drastically to only 15\% (Figs. 3a, 4a, b).

To test whether the receptor-binding site of $\mathrm{HN}$ was blocked by sialylated cell-surface components, the cells were treated with exogenous NA and subsequently tested for HAd activity. Like $\mathrm{SeV}$ neuraminidase, V.C. NA preferentially hydrolyzes $\alpha(2,3)$ linkages of sialic acids [24]. After V.C. NA treatment, erythrocyte binding was greatly enhanced at $39^{\circ} \mathrm{C}$ on cells infected with either HN mutant $262+264+461$ or $262+461$, whereas cells infected with HN mutant 262+264 showed a minor effect (Fig. 4a, c). The remaining HAd-negative cells during 262+264 infections might have been due to inefficient extracellular neuraminidase treatment, which is also unable to completely prevent LLC-MK $\mathrm{MK}_{2}$ cells from being infected with $\mathrm{SeV}$ wt (data not shown).

These results now allow an explanation of superinfection protection after infection with NA-deficient HN mutants: Mutant HN protein expressed in increasing amounts binds to receptors, leading to a quantitative formation of the $\mathrm{HN}-$ receptor complex and-when this binding persists- to a quantitative inactivation of the receptor.

Reduced incorporation of $\mathrm{HN}$ into mutant virus particles at $39^{\circ} \mathrm{C}$

HN incorporation into new virus particles could be hindered when shortly after de novo synthesis of HN protein 
all of the $\mathrm{HN}$ is bound to receptors and these complexes persist. Earlier results revealed that growth of a genetically modified HN-negative mutant was unimpaired by the presence of $\mathrm{HN}$ protein and that the $\mathrm{HN}$ content of virus particles was drastically reduced when infections with the NA-deficient Sendai virus mutant ts 271 were performed at $39^{\circ} \mathrm{C}[17,29,35]$. It therefore seemed probable that without interference with release of viral progeny, budding particles could contain less HN. Therefore, HN mutant particles propagated at $39^{\circ} \mathrm{C}$ were tested for $\mathrm{HN}$ insertion. To allow expression of the NA-inhibited HN phenotypes, cells were infected with stock virus generated at $33^{\circ} \mathrm{C}$ and incubated for $48 \mathrm{~h}$ at $39^{\circ} \mathrm{C}$-long enough to a generate sufficient amount of progeny virus. Analysis of released viral particles revealed a significantly reduced $\mathrm{HN}$ content for all three mutants (Fig. 5). The most drastic effect was observed with HN mutant $262+461$, which appeared to be released without any $\mathrm{HN}$ proteins. Only by overexposing the western blot was a faint signal obtained (data not shown). A similarly diminished $\mathrm{HN}$ content was detected with HN $262+264+461$, showing only $10 \%$ of the $\mathrm{HN}$ quantity detected in wt particles, whereas in mutant $\mathrm{HN}$ $262+264$, a relatively moderate but also clearly reduced HN content (25\%) was observed (Fig. 5). These results indicate that $\mathrm{HN}$ insertion into $\mathrm{SeV}$ depends on functional NA. In cells infected with NA-deficient $\mathrm{HN}$ mutants $262+461$ and $262+264+461$, HN proteins were

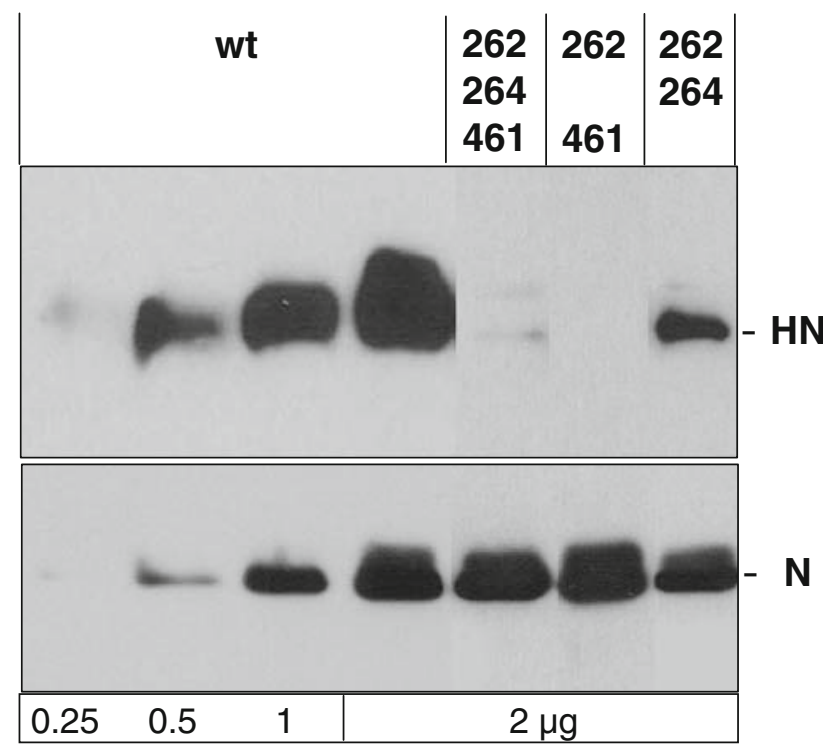

Fig. $5 \mathrm{HN}$ protein content in mutant virus progeny generated at $39^{\circ} \mathrm{C}$. Virus production was performed essentially as described in Fig. 1a. Protein separation by SDS-PAGE was performed with quantities corresponding to $1 / 60$ of the respective total virus protein. Immunodetection was performed with $\mathrm{HN}$-specific (VII3c-4F) $\mathrm{mAB}$ and monospecific anti-N serum. Signals of diluted and undiluted N protein served as an internal control and for quantification. X-ray films were exposed to antibody-treated membranes for about $4 \mathrm{~s}$ continuously engaged in receptor binding, and therefore incorporation into viral progeny was hindered.

\section{Discussion}

In the present work, the question is addressed whether $\mathrm{SeV}$ $\mathrm{HN}$ with functional binding activity but defective NA is capable of receptor inactivation. It is well known that the first step in the receptor-destruction process is a temporary binding of $\mathrm{HN}$ to receptors, rapidly followed by cleavage of sialic acid by NA. These consecutive processes happen very quickly and could not be separated so far. Based on data on Sendai virus mutants from persistent infections [25], we suspected that for quantitative receptor inactivation, continuous binding to newly synthesized $\mathrm{HN}$ might be sufficient without any NA activity. To answer the question of whether NA-deficient $\mathrm{HN}$ mutants are able to inactivate receptors quantitatively, for the first time, superinfection assays were employed as a highly sensitive test system using eGFP-expressing Sendai virus as homologous challenge virus. These assays allow detection of single challenge virus entry via non-inactivated virus receptors on infected cells, which was not possible in earlier transduction or superinfection studies based on viral progeny $[10,15,22]$.

Superinfection protection requires efficient binding of mutant virus to cells and efficient $\mathrm{HN}$ production in infected cells. The receptor-binding activity of mutated HN was demonstrated by determining infection rates of the mutant viruses, which were comparable to the wt virus. Normal quantities of mutant $\mathrm{HN}$ in the cytoplasm and on the surface of infected cells were detectable (Fig. 1a, c). In contrast to our approach, this state was not attained in cells transduced with wt hPIV3 HN or the NA-deficient mutant HN (C28a), since homologous superinfection was detectable [10]. In order to achieve efficient superinfection protection, the time point of challenge virus addition has to be chosen carefully. After an infection time of $5 \mathrm{~h}$, ca. $50 \%$ of the cells were unprotected against superinfection, whereas $24 \mathrm{~h}$ after primary infection, cells could no longer be infected by the challenge virus (Fig. 2a, b). We suppose that during progress of virus replication, the number of newly synthesized $\mathrm{HN}$ proteins exceeds that of the receptor molecules.

Newly synthesized HN 262+264+461 and 262+461 quantitatively blocked homologous superinfection of cells, and this was independent of the infection temperature (Fig. 3a), whereas the challenge virus alone efficiently expressed fluorescence in unprotected cells. The results of homologous (Fig. 3a) and heterologous superinfection (Fig. 3b) assays reveal that mutant HN blocks homologous superinfection specifically and not only due to cellular 
stress caused by the infection process. Hemadsorption on the cell surface can be restored by NA treatment and HN incorporation into viral progeny is restricted by continuous binding to sialylated receptors. Therefore, it is more likely that receptors are present but inactivated through binding to $\mathrm{HN}$ than that viral infection downregulates receptor synthesis, as believed in the case of the lentivirus CD4 receptor [27]. These experiments clearly demonstrate that in the absence of NA activity, receptors remain bound to $\mathrm{HN}$, leading to protection against superinfection, and that binding of mutant $\mathrm{HN}$ to receptors is reversible-by application of external neuraminidase.

Cells infected with $\mathrm{HN}$ mutant $262+264$ at $33^{\circ} \mathrm{C}$ blocked superinfection almost completely, whereas at $39^{\circ} \mathrm{C}$, infected cells were clearly superinfected (Fig. 3a). This result suggests that a HN phenotype with insufficient receptor-binding affinity was obtained at elevated temperature. The HN-binding activity by mutant $262+264$ does not seem to be strong enough to inactivate receptors completely, thus allowing homologous superinfection.

A number of mutated HNs generated by different laboratories $[3,13,34]$ were characterized in hemadsorption and NA assays as HN variants with simultaneously reduced binding and NA activity. These results are based on the assumption that the ligands had unrestricted accessibility to HN. However, when $\mathrm{HN}$ cannot be released from the receptor due to the lack of NA, HN, in turn, would not be available to bind other ligands, such as erythrocytes. Thus, interpretations of results from previous hemadsorption and NA assays typically employed in this type of study should be reconsidered [3, 34]. According to our results, newly synthesized $\mathrm{HN}$ is first targeted to binding to receptors. Consequently, only after NA is active and removed bound receptors can $\mathrm{HN}$ attain the ability to bind erythrocytes. The conclusion that HAd binding activity depends on the efficiency of NA in releasing HN from HN-receptor complexes was confirmed in various ways: (1) Most of the cells infected with the HN$262+264+461$ or $\mathrm{HN}-262+461$ mutant lost the HAd activity they had at $33^{\circ} \mathrm{C}$ when the infection temperature was increased, concomitantly with a loss of detectable NA activity (Figs. 1b, 4b). (2) When the deficiency in viral NA activity was compensated using bacterial NA, HN$262+264+461$ and HN-262+461-bound to receptorsgain the ability to bind erythrocytes (Fig. 4a, c). The observations of Connaris et al. [3] and Mirza et al. [20] can be interpreted in the context of a similar NA-triggered hemadsorption activity. Reduced erythrocyte binding of mutated HN has been described to be accompanied by strongly reduced NA activity.

Until now, the functional relevance of amino acids 262, 264 and 461 was neither recognizable from their classification as highly conserved amino acids nor by identification as active site residues due to structure analysis data. However, an influence on NA activity could be suggested by the proximity of amino acids 262 and 264 to the "NRKSCS motif" at positions 254-259 in SeV HN, a highly conserved region among parainfluenzaviruses [20]. Moreover, conformational implications could also be thought to have an influence, because positions 262 and 264 lie between C258 and C271, which form a disulfide bridge in the human parainfluenzavirus $3 \mathrm{HN}$ protein, the closest "sequence" relative of the SeV HN [16].

Absence of NA activity was associated with a drastically reduced $\mathrm{HN}$ content in mutant progeny particles generated at $39^{\circ} \mathrm{C}$ (Fig. 5). This is in accordance with earlier results obtained with mutant ts 271 . Reduced HN incorporation into ts 271 virus particles occurred in combination with significantly reduced NA activity at elevated temperature but without significantly reduced virus budding $[30,35]$. We assume that $\mathrm{HN}$ incorporation into virus particles might be inhibited to the same extent that HN remains bound to sialylated cell-surface components. The receptorcleavage function of newly synthesized $\mathrm{HN}$ seems to play an essential role with regard to the HN content of virus particles and consequently to the infectivity of viral progeny.

Based on our results, the two steps of HN-receptor interaction need to be interpreted in a new light: (1) HN binds very efficiently to receptors, thus leading to quantitative inhibition of receptor function, as demonstrated by superinfection protection. (2) By cleavage of a neuraminic acid residue by NA, the receptor is destroyed and, in parallel, $\mathrm{HN}$ is released from the complex, allowing it to be incorporated into new virus particles. This situation is thought to depend strictly on the amount of each of the two binding partners present during the viral life cycle. When, at the beginning of an infection, many receptors but only a few HN molecules are present, all of the HN should be bound to the receptors and have to be released by NA action. However, later during infection, when $\mathrm{HN}$ is expressed in excess, the majority of HN could follow the secretory pathway without binding to receptors. Finally, when HAd-competent $\mathrm{HN}$ molecules and destroyed receptors are detectable at the surface of wt infected cells, it is impossible to determine whether the $\mathrm{HN}$ and receptors came in contact early in their pathways or whether this interaction happened later on when receptors and $\mathrm{HN}$ were already inserted into the cell membrane, or even when HN was incorporated into the envelope of viral progeny.

Receptor inactivation in the absence of NA activity during infections with mutant $\mathrm{HN}-262+461$ and $\mathrm{HN}$ $262+264+461$ is a quantitative process. In order for this process to reach adequate efficiency, we conclude that it takes place soon after HN protein synthesis, before assembly of progeny virus particles. Therefore, the mechanism 
involved must differ from the receptor-destroying NA activity during budding and re-binding of virus particles [23]. When functional receptors would have to be cleaved by newly assembled progeny virus as a requirement for their release from the cell, it would be difficult to explain for our mutant virus by which mechanism superinfection of cells is inhibited when NA is absent. The spread of paramyxoviruses in tissues depends on the efficient release of viral progeny from primary infected cells, leading to further cell infections. NA inhibitors are applied extracellularly to inhibit that viral spread to neighboring cells $[1,38]$. When, as shown with our mutants, receptor inactivation and receptor destruction are already finished before the process of virus budding has started, the effects of antiviral drugs should be rather directed toward preventing paramyxoviral progeny from adsorption to new, uninfected cells. The principle of early receptor inactivation by intracellular HNreceptor binding — as supposed here-would allow virus particles unimpeded release from infected cells, and this would represent another example of viral evolution.

Acknowledgments We thank A. Portner for providing anti-HN antibody S2. This work was supported by grants from the Bundesministerium für Bildung und Forschung (AZ: 0312193) and from the European Commission (QLK2-2002-01722).

Open Access This article is distributed under the terms of the Creative Commons Attribution Noncommercial License which permits any noncommercial use, distribution, and reproduction in any medium, provided the original author(s) and source are credited.

\section{References}

1. Alymova IV, Taylor G, Takimoto T, Lin T-H, Chand P, Babu YS, Li C, Xiong X, Portner A (2004) Efficacy of novel hemagglutinin-neuraminidase inhibitors BCX 2798 and BCX 2855 against human parainfluenza viruses in vitro and in vivo. Antimicrob Agents Chemother 48:1495-1502

2. Bitzer M, Ungerechts G, Bossow S, Graepler F, Sedlmeier R, Armeanu S, Bernloehr C, Spiegel M, Gross CD, Gregor M, Neubert WJ, Lauer UM (2003) Negative-strand RNA viral vectors: intravenous application of Sendai virus vectors for the systemic delivery of therapeutic genes. Mol Ther 7:210-217

3. Connaris H, Takimoto T, Russell R, Crennell S, Moustafa I, Portner A, Taylor G (2002) Probing the sialic acid binding site of the hemagglutinin-neuraminidase of Newcastle disease virus: identification of key amino acids involved in cell binding, catalysis, and fusion. J Virol 76:1816-1824

4. Crennell S, Takimoto T, Portner A, Taylor G (2000) Crystal structure of the multifunctional paramyxovirus hemagglutininneuraminidase. Nat Struct Biol 7:1068-1074

5. Deppert W, Hanke K, Henning R (1980) Simian virus 40 $\mathrm{T}$-antigen-related cell surface antigen: serological demonstration on simian virus 40-transformed monolayer cells in situ. J Virol 35:505-518

6. Ferreira L, Villar E, Munoz-Barroso I (2004) Gangliosides and $\mathrm{N}$-glycoproteins function as Newcastle disease virus receptors. Int J Biochem Cell Biol 36:2344-2356
7. Fujii I, Iwabuchi Y, Teshima T, Shiba T, Kikuchi M (1993) $\mathrm{X}$-Neu5Ac: a novel substrate for chromogenic assay of neuraminidase activity in bacterial expression systems. Bioorg Med Chem 1:147-149

8. Gorman WL, Takahashi T, Scroggs RA, Portner A (1991) Identification of amino acid positions associated with neuraminidase activity of the hemagglutinin-neuraminidase glycoprotein of Sendai virus. Virology 180:803-806

9. Holmgren J, Svennerholm L, Elwing H, Fredman P, Strannegard O (1980) Sendai virus receptor: proposed recognition structure based on binding to plastic-adsorbed gangliosides. Proc Natl Acad Sci USA 77:1947-1950

10. Horga M-A, Gusella GL, Greengard O, Poltoratskaia N, Porotto M, Moscona A (2000) Mechanism of interference mediated by human parainfluenza virus type 3 infection. J Virol 74:1179211799

11. Horton RM (1993) In vitro recombination and mutagenesis of DNA. In: White BA (ed) Methods in molecular biology, PCR protocols: currant methods and applications, vol 15. Humana Press, Totowa, pp 251-261

12. Iorio RM, Glickman RL, Riel AM, Sheehan JP, Bratt MA (1989) Functional and neutralization profile of seven overlapping antigenic sites on the $\mathrm{HN}$ glycoprotein of Newcastle disease virus: monoclonal antibodies to some sites prevent viral attachment. Virus Res 13:245-262

13. Iorio RM, Field GM, Sauvron JM, Mirza AM, Deng R, Mahon PJ, Langedijk JP (2001) Structural and functional relationship between the receptor recognition and neuraminidase activities of the Newcastle disease virus hemagglutinin-neuraminidase protein: receptor recognition is dependent on neuraminidase activity. J Virol 75:1918-1927

14. Iwasaki Y, Koprowski H, Mueller D, ter Meulen V, Kaeckell YM (1973) Morphogenesis and structure of a virus in cells cultured from brain tissue from two cases of multiple sclerosis. Lab Invest 28:494-500

15. Kimura Y, Norrby E, Nagata I, Ito Y, Shimokata K (1976) Homologous interference induced by a temperature-sensitive mutant derived from an HVJ (Sendai virus) carrier culture. J Gen Virol 33:333-343

16. Lawrence MC, Borg NA, Streltsov VA, Pilling PA, Epa VC, Varghese JN, McKimm-Breschkin JL, Colman PM (2004) Structure of the haemagglutinin-neuraminidase from human parainfluenza virus type III. J Mol Biol 335:1343-1357

17. Leyrer S, Bitzer M, Lauer U, Kramer J, Neubert WJ, Sedlmeier R (1998) Sendai virus-like particles devoid of haemagglutininneuraminidase protein infect cells via the human asialoglycoprotein receptor. J Gen Virol 79:683-687

18. Leyrer S, Neubert WJ, Sedlmeier R (1998) Rapid and efficient recovery of Sendai virus from cDNA: factors influencing recombinant virus rescue. J Virol Methods 75:47-58

19. Markwell MAK, Paulson JC (1980) Sendai virus utilizes specific sialyloligosaccharides as host cell receptor determinants. Proc Natl Acad Sci U S A 77:5693-5697

20. Mirza AM, Deng R, Iorio RM (1994) Site-directed mutagenesis of a conserved hexapeptide in the paramyxovirus hemagglutininneuraminidase glycoprotein: effects on antigenic structure and function. J Virol 68:5093-5099

21. Martin A, Staeheli P, Schneider U (2006) RNA polymerase II-controlled expression of antigenomic RNA enhances the rescue efficacies of two different members of the mononegavirales independently of the site of viral genome replication. J Virol 80:5708-5715

22. Morrison TG, McGinnes LW (1989) Avian cells expressing the Newcastle disease virus hemagglutinin-neuraminidase protein are resistant to Newcastle disease virus infection. Virology $171: 10-17$ 
23. Moscona A (2005) Entry of parainfluenza virus into cells as a target for interrupting childhood respiratory disease. J Clin Invest 115:1688-1698

24. Moustafa I, Connaris H, Taylor M, Zaitsev V, Wilson JC, Kiefel MJ, von Itzstein M, Taylor G (2004) Sialic acid recognition by Vibrio cholerae neuraminidase. J Biol Chem 279:40819-40826

25. Neubert WJ, Hofschneider PH, Koprowski H (1983) Search for Sendai 6/94 viral RNA in the antigen-free cell line Cl-C-2 isolated from human multiple sclerosis brain tissue. Infect Immun 41:675-682

26. Peterson GL (1983) Determination of total protein. Methods Enzymol 91:95-119

27. Piguet V, Schwartz O, LeGall S, Trono D (2006) The downregulation of CD4 and MHC-I by primate lentiviruses: a paradigm for the modulation of cell surface receptors. Immunol Rev 168:51-63

28. Porotto M, Murrell M, Greengard O, Lawrence MC, McKimmBreschkin JL, Moscona A (2004) Inhibition of parainfluenza virus type 3 and Newcastle disease virus hemagglutinin-neuraminidase receptor binding: effect of receptor avidity and steric hindrance at the inhibitor binding sites. J Virol 78:13911-13919

29. Portner A, Marx PA, Kingsbury DW (1974) Isolation and characterization of Sendai virus temperature-sensitive mutants. J Virol 13:298-304

30. Portner A, Scroggs RA, Marx PA, Kingsbury DW (1975) A temperature-sensitive mutant of Sendai virus with an altered hemagglutinin-neuraminidase polypeptide: consequences for virus assembly and cytopathology. Virology 67:179-187

31. Portner A, Scroggs RA, Metzger DW (1987) Distinct functions of antigenic sites of the HN glycoprotein of Sendai virus. Virology 158:61-68

32. Roux L, Waldvogel FA (1982) Instability of the viral M protein in BHK-21 cells persistently infected with Sendai virus. Cell 28:293-302

33. Schneider H, Spielhofer P, Kaelin K, Dötsch C, Radecke F, Sutter G, Billeter MA (1997) Rescue of measles virus using a replication-deficient vaccinia-T7 vector. J Virol Methods 64:57-64
34. Sheehan JP, Iorio RM (1992) A single amino acid substitution in the hemagglutinin-neuraminidase of Newcastle disease virus results in a protein deficient in both functions. Virology 189:778781

35. Stricker R, Roux L (1991) The major glycoprotein of Sendai virus is dispensable for efficient virus particle budding. J Gen Virol 72:1703-1707

36. Sutter G, Ohlmann M, Erfle V (1995) Non-replicating vaccinia vector efficiently expresses bacteriophage T7 RNA polymerase. FEBS Lett 371:9-12

37. Suzuki T, Portner A, Scroggs RA, Uchikawa M, Koyama N, Matsuo K, Suzuki Y, Takimoto T (2001) Receptor specificities of human respiroviruses. J Virol 75:4604-4613

38. Suzuki T, Ikeda K, Koyama N, Hosokawa C, Kogure T, Takahashi T, Jwa Hidari KI-P, Miyamoto D, Tanaka K, Suzuki Y (2001) Inhibition of human parainfluenza virus type 1 sialidase by analogs of 2-deoxy-2, 3-didehydro- $N$-acetylneuraminic acid. Glycoconj J 18:331-337

39. Takahashi T, Ryan KW, Portner A (1992) Expression of cDNA encoding the Sendai virus hemagglutinin-neuraminidase gene: characterization of wild-type and mutant gene products. Virology 187:837-840

40. ter Meulen V, Koprowski H, Iwasaki Y, Kaeckell YM, Mueller D (1972) Fusion of cultured multiple-sclerosis brain cells with indicator cells: presence of nucleocapsids and virions and isolation of parainfluenza-type virus. Lancet 7766:1-5

41. Thompson SD, Portner A (1987) Localization of functional sites on the hemagglutinin-neuraminidase glycoprotein of Sendai virus by sequence analysis of antigenic and temperature-sensitive mutants. Virology 160:1-8

42. Villar E, Barroso IM (2006) Role of sialic acid-containing molecules in paramyxovirus entry into the host cell: a minireview. Glycoconj J 23:5-17

43. Yuan P, Thompson TB, Wurzburg BA, Paterson RG, Lamb RA, Jardetzky TS (2005) Structural studies of the parainfluenza virus 5 hemagglutinin-neuraminidase tetramer in complex with its receptor, sialyllactose. Structure 13:803-815 